\title{
Yurisdiksi ICC terhadap Negara non Anggota Statuta Roma 1998
}

\author{
Oleh: Sefriani \\ Dosen FH UII Yogyakarta \\ E mail:
}

\begin{abstract}
State Parties of Rome Satute 1998 have a territorial jurisdiction over the crimes which occured on their territorial. This is applied for all authors which come from the state parties and non state parties.
\end{abstract}

Keywords: Yurisdiksi, ICC, Statuta Roma

\section{Pendahuluan}

Bagi masyarakat internasional, 11 April 2002 merupakan suatu tanggal bersejarah baru bagi perkembangan serta penegakan hukum internasional. Karena pada hari itu, sepuluh negara meratifikasi Rome Statute for International Criminal Court 1998 sekaligus. Jumlah ini menggenapkan negara yang telah meratifikasi Statuta ICC menjadi 60 negara. Ini berarti persyaratan pemberlakuan International Criminal Court (ICC) sudah terpenuhi

Kehadiran International Criminal Court (ICC) melalui Statuta Roma 1998-nya di tahun 2002 tersebut seakan menjadi penyegar dahaga kurangnya lembaga penegak hukum bagi masyarakan internasional. Kehadiran ICC merupakan missing link setelah terbentuknya International Court of Justice (ICJ) yang hanya memiliki kewenangan terhadap perkara dengan negara sebagai subyeknya. Bahwa masyarakat internasional menyambut positif kehadiran lembaga ini terbukti dari relatif singkatnya waktu (4 tahun) untuk terpenuhinya syarat 60 piagam ratifikasi. ${ }^{1}$ Saat ini

\footnotetext{
${ }^{1}$ Bandingkan dengan Konvensi Hukum Laut PBB 1982 yang membutuhkan waktu sekitar 14 tahun untuk memenuhi syarat yang sama mengumpulkan 60 piagam ratifikasi.
} 
sudah lebih dari 100 negara menyatakan diri terikat pada instrumen hukum internasional tersebut. Hal ini juga dapat diartikan bahwa sesungguhnya masyarakat internasional menaruh harapan besar akan lebih baiknya penegakan hukum terhadap pelaku kejahatan internasional dengan kehadiran ICC.

Sangat menarik alasan yang dikemukakan Inggris, Prancis, Kanada dan Italia dan sebagian besar negara anggota NATO dalam mendukung kehadiran ICC. Menurut mereka keberadaan ICC dapat mencegah tentara-tentara mereka yang sedang bertugas di luar negeri untuk melakukan pelanggaran. ${ }^{2}$ Alasan ini sangat bertolak belakang dengan kekhawatiran Amerika pada yurisdiksi ICC mengingat lebih dari 200 ribu pasukannya berada di luar negeri untuk melaksanakan tugas negara atau sebagai bagian dari pasukan penjaga perdamaian Kekhawatiran ini berujung pada penolakan negara ini untuk mertaifikasi Statuta roma 1998. Di samping itu kehadiran lembaga ini menurut mereka juga untuk memberi peringatan kepada penguasa tiran bahwa tindak kejahatan yang mereka lakukan di negaranya tidak kebal dari tuntutan hukum internasional.

Berbeda dengan alasan-alasan yang dikemukakan pendukung ICC, Indonesia dan Negara-negara yang belum mau meratifikasi Statuta Roma 1998 memiliki kekawatiran bahwa ICC akan dapat melakukan intervensi terhadap kedaulatan negara. Kendati dalam mekanismenya, ICC memberikan kesempatan kepada peradilan nasional untuk mengadili pelaku. Dengan tidak meratifikasi berarti mereka bukan negara pihak dalam Statuta Roma 1998 sehingga dalam pandangan mereka, warga mereka tidak akan dapat disentuh ICC seandainya melakukan pelanggaran kejahatan internasional yang menjadi yurisdiski ICC adalah bertentangan dengan hukum international menurut beberapa negara penentang ICC khususnya Amerika Serikat, bilamana yurisdiksi ICC menjangkau negara yang bukan peserta Statuta roma 1998. Anggapan ini sah-sah saja dan sangat bisa dipahami mengingat dalam hukum perjanjian internasional dikenal suatu prinsip yang menyatakan "Pacta

${ }^{2}$ Alasan ini sangat bertolak belakang dengan kekawatiran Amerika pada yurisdiksi ICC mengingat lebih dari 200 ribu pasukannya berada di luar negeri untuk melaksanakan tugas negara atau sebagai bagian dari pasukan penjaga perdamaian. Kekawatiran ini berujung pada penolakan negara ini untuk mertaifikasi Statuta Roma 1998. 
Teriis nec Nocunt Nec prosunt" yang berarti bahwa perjanjian tidak memberikan hak dan kewajiban pada pihak ketiga tanpa persetujuannya. Namun demikian bagi para pendukung ICC dalam kondisi-kondisi tertentu tidaklah melanggar hukum internasional bilamana yurisdiksi ICC juga dapat menyentuh pelaku kejahatan internasional yang berasal dari non state party.

Dalam kaitannya dengan permasalahan di atas maka tulisan berikut akan mencoba menganalisis secara yuridis bagaimana sesungguhnya yurisdiksi ICC terhadap negara non anggota Statuta Roma 1998.

\section{Latar belakang pembentukan ICC}

Latar belakang pembentukan ICC tidak dapat dilepaskan dari sejarah pembentukan mahkamah-mahkamah kejahatan internasional sebelumnya. Sejarah yang pertama adalah pembentukan mahkamah kejahatan internasional pasca Perang Dunia Kedua, yaitu International Military Tribunal (IMT) atau dikenal sebagai Nuremberg Tribunal pada tahun 1945 dan International Military Tribunal for the Far East (IMTFE) pada 1946.

Pembentukan IMT didasarkan pada inisiatif sekutu yang memenangkan perang untuk mengadili para pemimpin Nazi-Jerman, baik sipil maupun militer, sebagai penjahat perang dengan terlebih dahulu dituangkan dalam London Agreement tanggal 8 Agustus 1945. Sedangkan IMTFE dibentuk berdasarkan Proklamasi Panglima Tertinggi Tentara Sekutu Jenderal Douglas MacArthur pada 1946. Kedua mahkamah memiliki persaman dan perbedaan. Persamaan keduanya adalah bahwa charter IMTFE merupakan hasil adopsi dari IMT. Selain itu, semangat dari pembentukan kedua mahkamah kejahatan internasional itu didasari oleh kedudukan sekutu sebagai pemenang dalam Perang Dunia Kedua, Sedangkan perbedaannya adalah sekalipun kedua charter memiliki content yang sama, dalam perangkat dan proses persidangannya sangat berbeda jauh. Sehingga, menghasilkan perbedaan yang cukup signifikan menyangkut putusan persidangan. Pada IMT, terdapat beberapa terdakwa yang diputus bebas, tetapi pada IMTFE tidak seorang pun lolos dari hukuman. Perbedaan lainnya terletak pada dasar hukum dari pembentukannya. Pada IMT, seluruh pemimpin Nazi-Jerman duduk di kursi pesakitan, sedangkan pada IMTFE, Kaisar Hirohito selaku pemimpin tertinggi Jepang tidak disentuh sama sekali. Ini disebabkan deal antara Pemerintah Jepang dengan Sekutu, dalam hal ini Amerika Serikat, untuk 
tidak mengganggu eksistensi Hirohito sebagai pemegang kedaulatan tertinggi Jepang. Berdasarkan perbedaan tersebut dapat disimpulkan bahwa kedua mahkamah tersebut tidak memiliki sifat independent dan impartial. ${ }^{3}$

Catatan sejarah yang kedua adalah pembentukan mahkamah kejahatan internasional setelah usai perang dingin, yaitu International Criminal Tribunal for fomer Yugoslavia (ICTY) dan International Criminal Tribunal for Rwanda (ICTR). Kedua mahkamah ini juga memiliki persamaan dan perbedaan. Persamaannya, kedua mahkamah dibentuk oleh lembaga yang sama, yaitu DK PBB melalui sebuah resolusi. Sedangkan perbedaannya adalah, pembentukan ICTY merupakan hasil dari evaluasi masyarakat internasional melalui DK PBB terhadap pelanggaran HAM berat yang terjadi di bekas Yugoslavia. Pembentukannya sendiri tidak mendapatkan dukungan, terutama dari "Yugoslavia baru" yang terdiri dari Serbia dan Montenegro. Meskipun terdapat kemajuan yang pesat dari kedua mahkamah kejahatan internasional pasca Perang Dunia Kedua, kedua mahkamah tersebut masih memiliki keterbatasan. Di antaranya, kurangnya pelaksanaan undang-undang-khususnya kerjasama dengan negara di mana pelanggaran HAM berat berlangsung, tidak bisa menghentikan konflik yang sedang berlangsung, serta jangkauan dari penuntutan tergantung dari kategori konflik yaitu konflik internal atau internasional. ${ }^{4}$

Belajar dari sejarah pembentukan 4 mahkamah sebelumnya yang kesemuanaya ad hoc serta memiliki berbagai kelemahan sebagaimana telah dikemukakan di atas maka keinginan untuk memiliki mahkamah yang permanen semakin dirasakan sebagai kebutuhan yang sudah tak bisa ditawar lagi. Lembaga yang permanen seperti ICC diharapkan lebih memberikan efisiensi dan efektifitas penegakan hukum terhadap kejahatan-kejahatan internasional. Pasca operasional ICC diharapkan setiap kejahatan internasional yang masuk yurisdiksi ICC segera dapat diadili tanpa harus menunggu pembentukan pengadilan baru, statuta baru, termasuk penunjukan aparat-aparat penegak hukumnya.

3 "ICC: Suatu Tinjauan Politik dan Hukum" dalam www.hukumonline.com , 30/10/02, artikel tersebut merupakan ringkasan Tesis Bhatara Ibnu Reza, "International Criminal Court: Suatu Analisis Mengenai Order dalam Hubungan Intrenasional" pada Pasca Sarjana FISIP UI 2002

${ }^{4}$ Ibid 
Pembentukan pengadilan-pengadilan ad hoc dalam kasus-kasus sebelumnya selalu memakan waktu, biaya dan tenaga yang tidak sedikit. ${ }^{5}$

Kedudukan ICC dalam masyarakat internasional adalah sebagai international order. Hal ini terlihat dari tujuan dari international order, yaitu mewujudkan tujuan-tujuan dari masyarakat internasional yang bersifat mendasar, utama dan universal terdiri dari menjaga rasa aman para anggotanya dari kekerasan yang sewenang-wenang dengan membatasi kekerasan (menggambarkan jaminan penghormatan HAM dan penegakan hukum), pentaatan terhadap perjanjian (menggambarkan prinsip resiprositas), dan jaminan penghormatan terhadap hak milik (mengambarkan prinsip pengakuan terhadap kedaulatan negara). ICC dianggap sebagai sebuah order karena dibentuk oleh masyarakat internasional. Tujuannya, sebagai sarana penegakan hukum internasional dan penghormatan terhadap HAM serta pencegahan praktek impunity terhadap pelanggaran HAM berat oleh aktor negara-bangsa. ${ }^{6}$

\section{Yurisdiksi ICC}

Pengadilan internasional yang berkedudukan di Den Haag-Belanda ini dibentuk melalui Statuta Roma (Rome Statute) 1998. Meskipun samasama berkedudukan di Den Haag namun institusi ini tidak ada kaitannya dengan lembaga pengadilan internasional lain yang merupakan salah satu organ utama PBB yaitu International Court of Justice (ICJ) atau yang lebih kita kenal dengan Mahkamah Internasional. ICJ dibentuk bersamaan dengan dibentuknya PBB pada tahun 1945, statutanya pun melekat pada piagam PBB (The Charter of United Nations) dan anggarannya berdasarkan anggaran PBB. Adapun ICC adalah independent institution, memiliki struktur organisasi sendiri terlepas dari PBB demikian halnya dengan anggaran operasionalnya yang didasarkan atas kontribusi negara-negara peserta dalam Statuta roma 1998. Dengan kata lain dapat dikatakan

${ }^{5}$ Pembentukan pengadilan ad hoc melalui Resolusi Dewan Keamanan PBB, dimana memerlukan proses yang rumit dan lama, melalui pemungutan suara yang memerlukan kesepakatan bulat lima anggota tetap lembaga tersebut, contoh-contoh rumit dan lamanya proses resolusi DK itu dapat dilihat pada Thomas M. Franck, Fairness in International Law and Institution, Clarendon Press, Oxford, 1999, hlm. 259, Bandingkan dengan Sumaryo Suryokusumo, Studi Kasus Organisasi Internasional, Edisi II, Alumni , Bandung, 1997, hlm. 32-33

${ }^{6}$ Bhatara Ibnu Reza, loc.cit 
bahwa ICC adalah subyek hukum internasional yang memiliki international personality.Dengan demikian ICC dapat melakukan berbagai international legal capacity dalam rangka pelaksanaan fungsinya. ${ }^{7}$ ICC dapat melaksanakan fungsi dan kewenangannya di wilayah Negara anggota juga dengan perjanjian khusus di wilayah Negara lain. ${ }^{8}$ Meskipun berkedudukan di Den Haag Belanda, ICC dapat menyelenggarakan sidang-sidangnya di negara-negara lain sesuai kebutuhan

Berkaitan dengan yurisdiksi atau kewenangan mengadili, maka ICC dibatasi oleh beberapa hal:

Pertama, berdasarkan subjek hukum yang dapat diadili atau personal jurisdiction (rationae personae), ICC hanya dapat mengadili individu.(natural person). Pelaku kejahatan dalam yurisiksi ICC harus mempertanggungjawabkan perbuatannya secara individu (individual responsibility), termasuk pejabat pemerintahan, komandan baik militer muapun sipil ${ }^{9}$

Kedua, berdasarkan jenis kejahatan yang menjadi ruang lingkupnya atau material jurisdiction (rationae materiae) maka yurisdiksi ICC adalah pada kejahatan-kejahatan yang merupakan kejahatan paling serius (the most serious crime) dalam pandangan masyarakat internasional yang diatur dalam Pasla 5-8 Statuta Roma 1998. Kejahatan-kejahatan dimaksud adalah sebagai berikut: ${ }^{10}$

a. the crime of genocide

b. crimes against humanity

c. war crimes

d. the crime of agression

Kejahatan genocide menurut Pasal 6 statuta adalah setiap tindakan yang dilakukan dengan maksud untuk merusak seluruhnya atau sebagian, suatu bangsa, etnik, ras, atau kelompok agama tertentu, seperti pembunuhan anggota-anggota kelompok, menyebabkan bahaya yang serius terhadap tubuh atau mental anggota kelompok, dengan sengaja menimbulkan kerusakan-kerusakan fisik kondisi-kondisi kehidupan kelompok, melakukan tindakan-tindakan secara paksa dengan maksud

\footnotetext{
${ }^{7}$ Pasal 4(1) Statuta Roma 1998

${ }^{8}$ Pasal 4(2) Statuta Roma 1998

${ }^{9}$ Pasal 25 Stauta Roma 1998. lihat juga ELSAM, Urgensi Rtaifikais Statuta Roma oleh Pemerintah Indoensia, Hasil penelitian, tanpa tahun.

${ }^{10}$ Pasal 5 Statuta Roma 1998
} 
untuk mencegah kelahiran dalam kelompok, dengan paksa memindahkan anak dari satu kelompok ke kelompok lain.

Kejahatan terhadap kemanusiaan menurut Pasal 7 Statuta adalah setiap tindakan yang dilakukan sebagai bagian dari serangan langsung yang luas atau sistematik terhadap penduduk sipil (civilian population), dengan pengetahuan tentang serangan. Tergolong dalam kejahatan terhadap kemanusiaan ini adalah pembunuhan, pemusnahan (extermination), perbudakan (enslavement), deportasi atau pemindahan paksa penduduk, pemenjaraan atau penghilangan kebebasan fisik secara kejam yang merupakan pelanggaran terhadap kaidah-kaidah dasar hukum internasional, penyiksaan (torture), perkosaan, perbudakan sex, prostitusi secara paksa, kehamilan secara paksa, sterilisasi secara paksa, atau setiap bentuk lain dari kekerasan sexual, penyiksaan terhadap kelompok yang diidentifikasikan kolektivitas politik, ras, negara, etnis, budaya, agama, dan gender, penghilangan orang secara paksa, serta kejahatan apartheid. Di samping itu setiap tindakan lain yang diluar perikemanusiaan atau yang berkarakter sama yang dilakukan dengan sengaja dengan maksud untuk menimbulkan penderitaan yang sangat (great suffering), luka yang serius (serious injury) fisik maupun mental pada korban adalah termasuk juga dalam kategori kejahatan terhadap kemanusiaan. ${ }^{11}$

Kejahatan perang menurut Pasal 9 Statuta antara lain adalah pelanggaran-pelanggaran berat (grave breaches) terhadap Konvensi Geneva 1949. Tindakan-tindakan yang dimaksud antara lain pembunuhan dengan sengaja, penyiksaan atau perlakuan tidak manusiawi termasuk eksperimen biologi, dengan sengaja menyebabkan penderitaan yang berat atau luka yang serius terhadap tubuh, perusakan secara luas dan pengambilan milik yang tidak sah, memaksa tawanan perang atau orang-orang lain yang dilindungi untuk membantu kekuatan musuh, dengan sengaja menghilangkan hak-hak tawanan perang dan orang-orang yang dilindungi dari peradilan yang jujur dan reguler, deportasi dan pemenjaraan yang melawan hukum serta melakukan penyanderaan. ${ }^{12}$

Berkaitan dengan kejahatan agresi statuta tidak memberikan penjelasan sebagaimana 3 kategori kejahatan sebelumnya yang dijelaskan secara rinci dalam pasal-pasal tertentu. Mengenai kejahatan ini statuta hanya menjelaskan bahwa piagam PBB menjadi rujukan untuk kejahatan

\footnotetext{
${ }^{11}$ Pasal 7 Statuta Roma 1998

${ }^{12}$ Pasal 8 Statuta Roma 1998
} 
ini. ${ }^{13}$ Berkaitan dengan hal ini, Piagam juga tidak memberikan penjelasan mengenai kejahatan agresi, kecuali menetapkan bahwa berdasarkan BAB VII Piagam Dewan Keamanan berhak mengambil tindakan-tindakan secara bertahap sampai dengan pengerahan pasukan multinasional bilamana terjadi tindakan-tindakan yang mengancam perdamaian internaisonal serta pelanggaran agresi. Tidak adanya penjelasan mengenai apa yang dimaksud kejahatan agresi ini sedikit banyak tentu merupakan kelemahan bagi statuta. Hal ini dapat menimbulkan berbagai penafsiran dan berdampak pada tidak adanya kepastian hukum pada pihak-pihak yang dituduh melakukan kejahatan tersebut.

Ketiga, berdasarkan waktunya atau temporal jurisdiction (ratione temporis), ICC hanya memiliki yurisdiksi terhadap kejahatan yang dilakukan setelah berlakunya Statuta Roma, yaitu 1 Juli 2002. ${ }^{14}$ Bilamana suatu negara menjadi pihak setelah berlakunya Statuta, maka ICC hanya memiliki yurisdiksi terhadap kejahatan yang dilakukan setelah Statuta berlaku terhadap negara tersebut. kecuali jika negara tersebut membuat deklarasi sebagaimana disyaratkan dalam Pasal 12 paragraf 3 Statuta.

Keempat, berdasarkan wilayah tempat dilakukannya kejahatan atau territorial jurisdiction ( rationae loci), maka ICC dapat mengadili kasus-kasus yang diserahkan oleh negara peserta yang wilayahnya menjadi tempat dilakukannya kejahatan internasional. Termasuk dalam pengertian ini adalah negara dimana kapal atau pesawat didaftarkan jika kejahatan dilakukan di atas kapal atau pesawat negara peserta. Di samping itu yurisdiksi ICC juga berlaku dalam wilayah bukan negara pihak yang mengakui yurisdiksi ICC berdasarkan deklarasi ad hoc. ${ }^{15}$

Dari pasal di atas dapat disimpulkan bahwa meskipun suatu negara bukan negara peserta Statuta Roma namun ICC dapat memiliki yurisdiksi terhadap pelaku kejahatan yang berasal dari negara tersebut bilamana kejahatan dilakukan di wilayah negara peserta Statuta dan negara tersebut menyerahkan kasus itu pada ICC.

Di samping negara peserta, ICC juga dapat melaksanakan yurisdikinya terhadap kasus yang diserahkan oleh Dewan Keamanan dalam rangka BAB VII Piagam Dewan Keamanan. Namun demikian berkaitan dengan Dewan Keamanan ini ternyata Statuta memberikan kewenangan pada Dewan

\footnotetext{
${ }^{13}$ Pasal 5(2) Statuta Roma 1998

${ }^{14}$ Lihat Pasla 11 Statuta Roma 1998

${ }^{15}$ Lihat Pasal 12 Statuta Roma 1998
} 
Keamanan untuk meminta ICC menunda pelaksanaan yurisdiksinya. Hal ini dapat disimpulkan dari apa yang ditetapkan oleh Pasal 16 Statuta: ...No investigation or prosecution may be commenced or proceeded with under this Statute for a period of 12 months after the Security Council, in a resolution adopted under Chapter VII of the Charter of the United Nations, has requested the Court to that effect; that request may be renewed by the Council under the same conditions.

Pasal 16 di atas merupakan hasil kompromi dari negara-negara pembentuk Statuta. Pasal ini dinilai banyak pihak merupakan pasal yang sangat sensitif dan berbahaya bagi pelaksanaan fungsi ICC ${ }^{16}$. Sebelumnya , Pasal 23(3) ILC Draft 1994 mengusulkan... "No prosecution may be commenced under this Statute arising from a situation which is being dealt with by the Security Council as a threat to or a breach of the peace or an act of aggression under Chapter VII of the Charter, unless the Security Council otherwise decides." Usulan ini ditentang oleh banyak delegasi dengan berbagai alasan termasuk keberatan terhadap dimungkinkannya Dewan menghentikan kewenangan ICC melaksanakan fungsinya secara independen ${ }^{17}$. Satu veto dari anggota tetap Dewan keamanan yang berdasarkan motivasi politik tertentu cukup untuk memblok ICC dalam melaksanakan fungsinya. ${ }^{18}$

Kompromi atas keberatan-keberatan yang diajukan terhadap draft ILC diperoleh dari proposal yang diajukan Singapura. Agustus 1997 Dalam proposal yang diajukannya Singapura mengusulkan untuk merevisi struktur hubungan ICC dengan Dewan Keamanan sebagai berikut: "[n]o investigation or prosecution may be commenced or proceeded with under this Statute where the Security Council has acting under Chapter VII of the Charter of the United Nations, given a direction to that effect."

Menambahkan proposal Singapura , Canada merekomendasikan ... a 12- month renewable deferral period. Adapun Costa Rica juga mengusulkan bahwa ... deferral requests be made by a "formal and specific decision" by the Security Council. ${ }^{19}$

${ }^{16}$ Mohamed El Zeidy, 2002, “The United States Dropped The Atomic Bomb of Article 16 of the ICC Statute :Security Council power of Deferrals and Resolution 1422", dalam Vanderbilt Journal of Transnational Law, November, 2002, hlm. 1510

${ }^{17}$ Lionel Yee, The International Criminal Court and the Security Council: Articles 13(b) and 16, in The International Criminal Court: The Making of the Rome Statute, Issues, Negotiations, Results 150 (Roy Lee ed., 1999), hlm. 124

${ }^{18}$ Morten Bergsmo et al., "Deferral of Investigation or Prosecution, in Commentary on the Rome Statute" , 64 Law \& Contemp. Probs. 1 (2000), hlm. 377

${ }^{19}$ Mohamed El Zeidy, op. cit., hlm. 1511 
Kedudukan ICC hanya sebagai institusi pelengkap bagi peradilan domestik yang dimiliki oleh masing-masing negara. Hal ini ditegaskan dalam Preambule paragraf 10 statuta yang menyatakan bahwa emphasizing that the ICC establishment under this statute shall be complementary to national criminal jurisdiction. Hal yang sama juga ditetapkan dalam Pasal 1 Statuta. ${ }^{20}$

Prinsip komplementaritas (complementarity principle) dalam Preambul maupun dalam Pasal 1 Statuta sebenarnya adalah untuk mengakomodasi pendapat-pendapat bahwa keberadaaan ICC akan bertentangan atau mengganggu prinsip-prinsip kedaulatan yang sangat dihormati dalam hukum internasional.Dengan kedudukan sebagai institusi komplementer atau sekunder sebagaimana ditetapkan di atas, jurisdiksi utama adalah tetap di tangan institusi nasional. Hukum nasional didahulukan untuk diterapkan terhadap kejahatan-kejahatan internasional yang terjadi di wilayah negara yang bersangkutan. ICC hanya dapat mengadili suatu praktek kejahatan kemanusiaan, kejahatan perang, kejahatan agresi dan genocide sepanjang pengadilan domestik tidak mau atau tidak mampu melaksanakan fungsinya. Pasal 17 tentang issues of admissibility menyatakan bahwa suatu kasus tidak dapat diterima (inadmissible) oleh ICC bilamana:

a. Kasusnya sedang diselidiki atau dituntut oleh suatu negara yang mempunyai yurisdiksi atas kasus tersebut, kecuali kalau negara tersebut tidak bersedia atau benar-benar tidak dapat melakukan penyelidikan atau penuntutan

b. Kasusnya telah diselidiki oleh suatu negara yang yang mempunyai yurisdiksi atas kasus tersebut, dan negara itu telah memutuskan untuk tidak menuntut orang yang bersangkutan, kecuali kalau keputusan itu timbul dari ketidaksediaan atau ketidakmampuan negara tersebut untuk benar-benar melakukan penuntutan

c. Orang yang bersangkutan telah diadili atas suatu perbuatan yang merupakan pokok pengaduan itu dan suatu sidang oleh mahkamah tidak diperkenankan berdasarkan Pasal 20(3)

d. Kasusnya tidak cukup gawat untuk membenarkan tindakan lebih lanjut oleh mahkamah

${ }^{20}$ Pasal 1 Statuta menyatakan bahwa an ICC is hereby established it shall be a permanent institusion and shall have the power to exercise its jurisdiction over persons for the..., and shall be complementary to national criminal jurisdiction ... 
Dalam upaya menetapkan adanya unwillingness suatu negara, ICC harus memperhatikan prinsip due process yang diakui oleh Hukum Internasional sebagai berikut:

a. proses pengadilan diambil atau putusan dibuat dengan maksud untuk melindungi orang yang seharusnya bertanggung jawab terhadap kejahatan-kejahatan yang menjadi yurisdiksi ICC

b. ada penundaan yang tidak dibenarkan dalam proses peradilan, yang tidak konsisten dengan tujuan untuk memberi keadilan pada tertuduh

c. proses peradilan tidak dilaksanakan dengan bebas atau memihak. dan dilaksanakan dengan cara dan dalam situasi tertentu, yang tidak sesuai dengan tujuan untuk membawa orang yang dituduh pada keadilan Untuk menetapkan ketidakmampuan (inability) negara, ICC harus mempertimbangkan apakah ada kegagalan keseluruhan atau pada substansi-subastansi tertentu ataukah tidak tersedianya sistem peradilan nasional, negara tidak dapat menangkap tertuduh, tidak dapat memperoleh bukti-bukti dan kesaksian penting, atau ketidakmampuan yang lain untuk melaksanakan sendiri proses peradilan. ${ }^{21}$

\section{Yurisdiksi ICC terhadap Warga Negara yang berasal dari non -State Party}

Berdasarkan Statuta Roma 1998 ICC memiliki yurisdiksi terhadap warga negara yang berasal dari non state parties dalam kondisi-kondisi sebagai berikut: ${ }^{22}$

a. Dalam kasus yang diserahkan oleh Dewan Keamanan PBB kepada ICC. ${ }^{23}$

b. Dalam kasus warga negara dari non state parties melakukan kejahatan di wilayah atau territorial negara anggota Statuta Roma atau Negara yang sudah menerima yurisdiksi ICC berkaitan dengan kejahatan tersebut. $^{24}$

c. Dalam kasus negara non state parties sudah menyetujui untuk melaksanakan yurisdiksi berkaitan dengan kejahatan-kejahatan tertentu. ${ }^{25}$

\footnotetext{
${ }^{21}$ Pasal 17 (3) Statuta Roma 1998

${ }^{22}$ Dapo Akande, 2003, “The Jurisdiction of International Criminal Court Over Nationals of Non-Parties: Legal Basis and Limits" dalam Journal of International Criminal Justice, 618, 2003, , December, 2003, hlm. 1

${ }^{23}$ Ibid, lihat Pasal 13 Statuta roma 1998

${ }^{24}$ Ibid, lihat Pasal 12 (2) (a) dan (3) Statuta Roma

${ }^{25} \mathrm{Ibid}$
} 
Setidaknya ada 1 negara non state parties yaitu Amerika Serikat yang mengajukan keberatan terhadap kondisi pertama dan kedua sebagaimana dipaparkan di atas yang mengabaikan persetujuan non state parties. ${ }^{26}$

Dalam perlawanan atau serangannya terhadap ICC, Amerika melakukan berbagai upaya, baik melalui jalur politik maupun hukum agar supaya ICC tidak dapat melaksanakan yurisdiksi terhadap warganya. Upaya-upaya atau strategi yang dilakukan Amerika Serikat antara lain sebagai berikut: ${ }^{27}$

1. Membuat peraturan dan perjanjian untuk membatasi yurisdiksi ICC dengan negara-negara pihak dalam Statuta Roma.

2. Membuat perjanjian dengan negara-negara lain yang melarang mentransfer warga Amerika Serikat ke ICC

3. Mengadopsi Resolusi Dewan Keamanan untuk mencegah pelaksanaan yurisdiksi ICC terhadap warga negara dari non state parties yang terlibat dalam operasi-operasi perdamaian PBB.

Menurut Amerika Serikat pelaksanaan yurisdiksi ICC terhadap warga dari non state parties bertentangan dengan prinsip-prinsip hukum internasional. ${ }^{28}$ Prinsip hukum yang dimaksud antara lain adalah Pacta tertiis nec nosunt nec prosunt. Prinsip yang berasal dari Romawi ini telah menjadi hukum kebiasaan internasional dan telah dikodifikasikan dalam Konvensi Wina 1969 tentang Perjanjian internasional. Menurut prinsip yang tertuang dalam pasal 34 Konvensi Wina 1969 ini suatu perjanjian tidak menimbulkan hak dan kewajiban bagi pihak ketiga tanpa persetujuannya.

Menanggapi keberatan yang di ajukan Amerika ini, M. Scharf mengemukakan bahwa sebenarnya tidak ada satu pasal pun dalam Statuta Roma yang membebani kewajiban pada pihak ketiga. ${ }^{29}$ Yang terjadi adalah bahwa dengan pelaksanaan yurisdiksi ICC tersebut akan mempengaruhi

${ }^{26}$ Ibid

${ }^{27}$ Ibid., hlm. 2

${ }^{28}$ United States: "State Department Fact Sheet on the International Criminal Court" [http://www.state.gov/s/wci/rls/ls/2002/9978.htm]. Lihat juga D. Scheffer, "The United States and the International Criminal Court" dalam . 93 American Journal of International Law (AJIL), (1999), hlm. 12 dan 18.

${ }^{29}$ M. Scharf, Op.Cit, hlm. 67, bandingkan dengan : D. Arnaut, " 'When in Rome ... The International Criminal Court and the Avenues for U.S. Participation" dalam 43 Virginia Journal of International Law (VJIL) (2003) hlm 405 juga Johnson. 'The American Servicemember's Protection Act: Protecting Whom?' dalam .43 Virginia Journal of International Law (VJIL), (2003), hlm. 444. 
kepentingan non state parties. Tentu saja hal ini sangat berbeda dengan membebani atau menciptakan suatu kewajiban sebagaimana yang diatur dalam pasal 34 Konvensi Wina 1969.

Pelanggaran hukum internasional kedua oleh ICC terhadap non state parties menurut Madeline Morris ${ }^{30}$ adalah bahwa ICC akan bertindak secara tidak sah jika melaksanakan yurisdiksinya terhadap warga negara dari non state parties yang sedang melaksanakan tugas resmi atau policy dari negaranya. Lebih lanjut Morris juga mengemukakan bahwa pelaksaan yurisdiksi ICC terhadap warga negara dari non state parties akan bertentangan dengan prinsip bahwa pengadilan internasional tidak dapat melaksanakan yurisdiksinya terhadap kasus-kasus menyangkut hak atau tanggung jawab pihak ketiga yang tidak memberikan persetujuan terhadap masalah pokok perselisihan. ${ }^{31}$

Menanggapi apa yang dikemukakan Morris, para pakar hukum internasional mengemukakan bahwa negara pihak Statuta Roma 1998 memiliki yurisdiksi teritorial terhadap segala kejahatan yang terjadi di wilayah atau teritorialnya. Hal ini berlaku terhadap pelaku kejahatan dari negara manapun baik negara pihak Stauta Roma maupun bukan (non state parties). Apabila kejahatan yang dilakukan masuk kategori international crime maka berdasarkan prinsip universal yang dikenal dalam hukum internasional semua negara memiliki yurisdiksi terhadap pelaku tanpa memperhatikan nasionalitas si pelaku maupun tempat dilakukannya kejahatan tersebut. Manakala suatu negara yang memiliki yurisdiski berkehendak melaksanakan yurisdiksinya maka persetujuan dari negara asal pelaku kejahatan tidaklah disyaratkan. Kewenangan ICC untuk mengadili pelaku kejahatan yang masuk kategori ruang lingkup yurisdiksinya merupakan pendelegasian dari negara pihak yang di wilayahnya terjadi kejahatan internasional dan negara tersebut tidak mampu atau tidak mau mengadili sendiri untuk kemudian menyerahkan pelaku untuk diadili di depan ICC. Dengan demikian bahwa ICC dapat melaksanakan yurisdiskinya terhadap anggota pasukan PBB yang berasal

\footnotetext{
${ }^{30}$ Madeline . Morris, "High Crimes and Misconceptions: The ICC and Non-Party States" dalam . Law \& Contemporary Problems (2001) 13, hlm. 27.Lihat juga William K.. Lietzau,"'International Criminal Law After Rome: Concerns from a U.S. Military Perspective" dalam 64 Law \& Contemporary Problems 119, winter 2001, hlm. 135.

${ }^{31}$ Monetary Gold Case (Italy v. France, United Kingdom and United States). ICJ Reports (1954) hlm 19; East Timor Case (Portugal v. Australia), ICJ Reports (1995), hlm. 90, sebagaimana dikutip oleh Dapo Akande, op. cit., hlm. 3
} 
dari non state party tidaklah melanggar hukum internasional. Dalam praktek hukum internasional ketika suatu negara akan mengekstradisikan pelaku kejahatan ke negara yang memintanya tidaklah disyaratkan adanya persetujuan dari negara asal si pelaku terlebih dahulu.

Berbagai konvensi menentang terorisme adalah contoh-contoh perjanjian yang dikatakan melahirkan prinsip universal. Secara umum konvensi-konvensi tesebut menetapkan bahwa semua negara yang di wilayahnya terdapat teroris berkewajiban untuk mengadili atau mengekstradisikannya ke negara lain yang bersedia mengadilinya. Amerika sebagai negara pihak dalam berbagai konvensi anti terorisme Amerika banyak melaksanakan yurisdiskinya terhadap pelaku yang diduga teroris yang berasal dari non pihak konvensi anti terorism.

Satu argumen lagi yang dapat diajukan untuk mendukung yurisdiski ICC atas warga non state party adalah bahwa Pasal 27 Statuta Roma 1998 mengatur tentang tidak relevannya jabatan resmi menetapkan sebagai berikut: 1. Statuta berlaku sama terhadap semua orang tanpa suatu perbedaan atas dasar jabatan resmi. Secara khusus, jabatan resmi sebagai seorang kepala negara atau pemerintahan anggota suatu pemerintahan atau parlemen, wakil terpilih atau pejabat pemerintah dalam hal apapun tidak mengecualikan seseorang dari tanggung jawab pidana di bawah statuta. Demikian pula dalam hal mengenai dirinya sendiri tidak merupakan suatu alasan untuk mengurangi hukuman.

2. Kekebalan atau peraturan procedural khusus yang mungkin terkait dengan jabatan resmi dari seseorang baik di bawah hukum nasional atau internasional tidak menghalangi mahkamah untuk melaksanakan yurisdiksinya atas orang tersebut

Pasal di atas tidak membedakan antara imunita personal dengan immunity ratione materiae. Sebaliknya Pasal 27 Statuta Roma 1998 merekomendasikan bahwa pejabat negara akan bertanggungjawab terhadap segala tindakan yang dilakukannya atas nama negara, pejabat negara di sini termasuk pejabat yang menikmati personal imunitas.

Di samping Pasal 27 pasal yang juga erat kaitannya dengan masalah ini adalah Pasal $28^{32}$ yang secara rinci menetapkan bahwa seorang atasan

\footnotetext{
${ }^{32}$ Bunyi Pasal 28 selengkapnya adalah sebagai berikut:Responsibility of commanders and other superiors In addition to other grounds of criminal responsibility under this Statute for crimes within the jurisdiction of the Court:
} 
baik militer maupun sipil harus bertanggungjawab secara pidana ketika terjadi kejahatan dalam yurisdiksi ICC yang dilakukan anak buahnya. Pasal ini bertujuan untuk dapat menghukum the most responsible person, walaupun orang tersebut memiliki posisi sebagai pemegang kekuasaan yang seringkali sulit terjangkau hukum.

Pasal 28 dimaksudkan untuk menghapuskan praktek impunitas. Secara umum impunitas dipahami sebagai tindakan yang mengabaikan penegakan hukum terhadap pelaku kejahatan atau dalam kepustakaan umum seringkali diartikan sebagai absence of punishment. Dalam perkembangannya istilah impunity digunakan hampir secara eksklusif dalam konteks hukum, untuk menandakan suatu proses dimana sejumlah individu luput dari berbagai bentuk penghukuman terhadap berbagai tindakan illegal maupun kriminal yang pernah mereka lakukan. ${ }^{33}$ Praktek impunitas ini telah terjadi sejak berabad yang lalu diantaranya adalah

(a) A military commander or person effectively acting as a military commander shall be criminally responsible for crimes within the jurisdiction of the Court committed by forces under his or her effective command and control, or effective authority and control as the case may be, as a result of his or her failure to exercise control properly over such forces, where: (i) That military commander or person either knew or, owing to the circumstances at the time, should have known that the forces were committing or about to commit such crimes; and

(ii) That military commander or person failed to take all necessary and reasonable measures within his or her power to prevent or repress their commission or to submit the matter to the competent authorities for investigation and prosecution.

(b) With respect to superior and subordinate relationships not described in paragraph (a ), a superior shall be criminally responsible for crimes within the jurisdiction of the Court committed by subordinates under his or her effective authority and control, as a result of his or her failure to exercise control properly over such subordinates, where: (i) The superior either knew, or consciously disregarded information which clearly indicated, that the subordinates were committing or about to commit such crimes;

(ii) The crimes concerned activities that were within the effective responsibility and control of the superior; and

(iii) The superior failed to take all necessary and reasonable measures within his or her power to prevent or repress their commission or to submit the matter to the competent authorities for investigation and prosecution.

${ }^{33}$ Abdul Hakim Garuda Nusantara, Sebuah upaya memutus rantai Impunitas: Tanggung jawab Komando dalam Pelanghgaran berat HAM, dalam Jurnal HAM KOMNAS HAM, Vol. 2. No. 2, Nopember 2004, hlm. 8 
gagalnya negara-negara Eropa untuk mengadili Raja Wilhelm II sebagaimana yang direkomendasikan oleh perjanjian Versailles, tidak diadilinya Kaisar Hirohito oleh Mahkamah Tokyo atas keputusan Amerika Serikat, berbagai pengadilan pura-pura yang mengadili serdadu-serdadu rendahan dengan hukuman yang sangat ringan dan melawan hati nurani keadilan masyarakat. ${ }^{34}$ Praktek ini menunjukkan bahwa setiap negara selalu memiliki kecenderungan untuk melindungi pelaku kejahatan yang merupakan warganegaranya sendiri apalagi bila pelaku tersbeut adalah orang yang memiliki pengaruh dan atau kekuasaan di Negara tersebut.

Demikianlah Pasal 27 juga 28 Statuta Roma 1998 memperkuat dukungan yurisdiksi ICC terhadap warga dari non state party karena terhadap kejahatan internasional yang menjadi yurisdiksi ICC tersebut berlakulah yurisdiski universal. Imunitas tidaklah relevan bagi siapapun, dari negara manapun, termasuk dari negara non state party dan dalam kapasitas atau jabatan apapun. Ketidakrelevanan imunitas terhadap pelaku kejahatan internaisonal sebenarnya telah ditegaskan dalam beberapa instrument hukum internaisonal sebelumnya seperti Pasal 227 Treaty Versailles yang menyatakan bahwa;

In the hierarchy of person in authority, there is no reason why rank, however exalted, should in any circumstances protect the holder of it from responsibility when that responsibility has been established before a properly constituted tribunal, This extends even to the case of heads of State

Hal serupa dimuat juga pada Pasal 7 The International Military Tribunal untuk Nuremberg dan Tokyo yang menyatakan bahwa: The official position of the defendant, whether asHeads of States or responsible officials in Governmnent departments, shall not be considered as freeing by legislation. Penegasan lebih lanjut mengenai tidak berlakunya imunitas pada pejabat-pejabat tinggi negera juga dapat ditemukan dalam Pasal II (4) (a) The 1945 Control Council Law10, Pasal IV the Genocide Convention, Prinsip II Nurenberg Principle 1950, Pasal III Apartheid Convention, serta Pasal 7(2) dan Pasal 6 (2) Statuta ICTY dan ICTR .

Kasus-kasus hukum dewasa ini juga menunjukkan tidak dapat diberlakukannya personal imunitas pada kejahatan internasional. Dalam

\footnotetext{
${ }^{34}$ Daniel Hutagalung, Negara dan pelanggaran MAsa Lalu :Tuntutan Pertanggungjawaban Versus Impunitas, dalam Jurnal HAM ELSAM, HaK untuk Menetukan Nasib Sendiri, VOl III.No1, 2005, hlm. 230-231
} 
kasus Furundza the ICTR Trial Chamber menyatakan bahwa Statuta ICTR dan ICTY ."are indisputably declaratory of customary international law". Selanjutnya ICTY dalam kasus tadi menyatakan bahwa norma-norma dalam Statuta Roma 1998 merepresentasikan opinio juris of the vast majority of States. Dalam kasus Eichmen Pengadilan distrik Yerusalem dan Pengadilan Tinggi Israel menolak pembelaan terdakwa yang menyatakan bahwa tindakannya atas nama negara Jerman. Pendekatan serupa juga ditemukan dalam putusan pengadilan aksus Filartiga v Pena-Irala case.

\section{Penutup}

Berdasarkan Statuta Roma 1998 ICC memiliki yurisdiksi terhadap warga negara yang berasal dari non state parties dalam kondisi-kondisi sebagai berikut:

1. Dalam kasus yang diserahkan oleh Dewan Keamanan PBB kepada ICC

2. Dalam kasus Warga Negara dari non state parties melakukan kejahatan di wilayah atau territorial negara anggota Statuta Roma atau negara yang sudah menerima yurisdiksi ICC berkaitan dengan kejahatan tersebut ${ }^{35}$

3. Dalam kasus negara non state parties sudah menyetujui untuk melaksanakan yurisdiksi berkaitan dengan kejahatan-kejahatan tertentu Negara pihak Statuta Roma 1998 memiliki yurisdiksi teritorial terhadap segala kejahatan yang terjadi di wilayah atau teritorialnya. Hal ini berlaku terhadap pelaku kejahatan dari negara manapun baik negara pihak Statuta Roma maupun bukan (non state parties). Apabila kejahatan yang dilakukan masuk kategori international crime maka berdasarkan prinsip universal yang dikenal dalam hukum internasional semua negara termasuk di dalamnya pengadilan internasional memiliki yurisdiksi terhadap pelaku tanpa memperhatikan nasionalitas si pelaku maupun tempat dilakukannya kejahatan tersebut, dan hal ini tidaklah bertentangan dengan hukum international.

\footnotetext{
${ }^{35} \mathrm{Ibid}$, lihat Pasal 12 (2) (a) dan (3) Statuta Roma
} 


\section{Daftar Pustaka}

Abdul Hakim Garuda Nusantara, "Sebuah upaya memutus rantai Impunitas: Tanggung jawab Komando dalam Pelanghgaran berat HAM", dalam Jurnal HAM KOMNAS HAM , Vol. 2 . No.2, Nopember 2004

"ICC: Suatu Tinjauan Politik dan Hukum" dalam www.hukumonline.com, 30/10/02, artikel tersebut merupakan ringkasan Tesis Bhatara Ibnu Reza dengan judul "International Criminal Court: Suatu Analisis Mengenai Order dalam Hubungan Intrenasional" pada Pasca Sarjana FISIP UI 2002

Daniel Hutagalung, Negara dan pelanggaran MAsa Lalu :Tuntutan Pertanggungjawaban Versus Impunitas, dalam Jurnal HAM ELSAM, HaK untuk Menentukan Nasib Sendiri, Vol. III.No1, 2005,

Dapo Akande, 2003, “The Jurisdiction of International Criminal Court Over Nationals of Non-Parties: Legal Basis and Limits" dalam Journal of International Criminal Justice, 618, 2003, , December, 2003

D. Arnaut, " 'When in Rome ... The International Criminal Court and the Avenues for U.S. Participation" dalam 43 Virginia Journal of International Law (VJIL) (2003)

D. Scheffer, "The United States and the International Criminal Court" dalam . 93 American Journal of International Law (AJIL), (1999)

Dinah Shelton, "Normative Hierarchi in International Law", dalam American Journal of International Law (AJIL) , 100 Am.J.Int'1 L.291, April, 2006

Eileen Denza, 1998, Diplomatic Law: A Commentary on the Vienna Convention on Diplomatic Relatiuons , $2^{\text {nd }}$ edition

Johnson. 'The American Servicemember's Protection Act: Protecting Whom?' dalam .43 Virginia Journal of International Law (VJIL) (2003)

Lionel Yee, The International Criminal Court and the Security Council: Articles 13(b) and 16, in The International Criminal Court: The Making of the Rome Statute, Issues, Negotiations, Results 150 (Roy Lee ed., 1999).

Johnson. 'The American Servicemember's Protection Act: Protecting Whom?'dalam .43 Virginia Journal of International Law (VJIL) (2003)

Louis B Sohn, “The Security Council's Role in the Settlement of International Disputes", Editorial Comment by the American Society of International Law, 78 American Journal of International law 402, April, 1984

Madeline . Morris, "High Crimes and Misconceptions: The ICC and NonParty States" dalam . Law \& Contemporary Problems (2001)

Morten Bergsmo et al., "Deferral of Investigation or Prosecution, in 
Commentary on the Rome Statute" , 64 Law \& Contemp. Probs. 1 (2000)

Mochtar Kusumaatmadja, Pengantar Hukum Internasional, Buku I Bagian Umum, Binacpta, Jakarta, catakan keempat, 1982

Mohamed El Zeidy, 2002, “The United States Dropped The Atomic Bomb of Article 16 of the ICC Statute :Security Council power of Deferrals and Resolution 1422", dalam Vanderbilt Journal of Transnational Law, November, 2002

Neha Jain, " A Separate Law for Peacekeepers: The Clash Between The Security Council and The International Criminal Court", dalam European Journal of International Law, April, 2005

Sumaryo Suryokusumo, Studi Kasus Hukum Organisasi Internasional, 1997, Alumni, Bandung Edisi II

Thomas M. Franck, Fairness in International Law and Institution, Clarendon Press, Oxford, 1999

United Nations, Teaching About United Nations Peacekeeping, UN, Department of Public Information, New York, 1990

United States: "State Department Fact Sheet on the International Criminal Court" [http://www.state.gov/s/wci/rls/1s/2002/9978.htm

William K. Lietzau,"'International Criminal Law After Rome: Concerns from a U.S. Military Perspective" dalam 64 Law \& Contemporary Problems 119, winter 2001 